\title{
Protonpumpehemmer forebygger medikamentindusert blødende magesår
}

\author{
Blødende magesår er en vanlig og alvorlig sykdom, og bivirkninger av medikamenter er ofte årsak. Mange \\ tilfeller kunne vært unngått hvis flere hadde fått profylakse med protonpumpehemmer. Norske retningslinjer \\ for slik profylakse mangler.
}

Opptil $90 \%$ av pasientene med blødende magesår (ulcus ventriculi og/eller ulcus duodeni) bruker medikamenter med kjent økt risiko for bivirkninger i form av ulcus og/eller gastrointestinal blødning (1). Risikoen for slike bivirkninger er størst hos eldre (2). De mest aktuelle medikamentene er ikke-steroide antiinflammatoriske midler (NSAID-preparater), acetylsalisylsyre, klopidogrel, warfarin, lavmolekylært heparin, steroider og selektive serotoninreopptakshemmere (SSRI) (1). Samtidig bruk av flere slike medikamenter kan medføre at risikoen hemmer vil også beskytte noe mot blødning fra andre lesjoner enn ulcus i øvre gastrointestinaltractus, men beskytter ikke mot blødning fra nedre gastrointestinaltractus (2).

I 2008 kom det i USA retningslinjer for profylakse med protonpumpehemmer hos pasienter som får ikke-steroide antiinflammatoriske midler og/eller platehemmere (2). I 2010 kom en oppdatering av retningslinjene, med spesiell vekt på profylakse hos pasienter som bruker klopidogrel eller andre thienopyridiner (7). Det er behov for

\section{«Hos pasienter som bruker ikke-steroide antiinflammatoriske midler og/eller blodplate- hemmere, kan profylakse med protonpumpe- hemmer redusere risikoen for blødende ulcus med ca. $70 \%$ »}

for blødende magesår mangedobles (2). De aktuelle medikamentene øker også risikoen for andre typer gastrointestinale blødninger (2). Her i landet øker forbruket av alle disse medikamentene (3). I tillegg er flere nye blodplatehemmere og antikoagulasjonsmidler blitt godkjent i Norge det siste året, og alle disse medikamentene gir økt risiko for gastrointestinal blødning (4-6).

De nye antikoagulasjonsmidlene anses som tryggere enn warfarin, bl.a. fordi faren for overdosering er mindre. Sannsynligvis vil et økende antall eldre der det er kontraindikasjoner mot warfarin, bli behandlet med de nye antikoagulasjonsmidlene. Dette kan føre til en økning i antallet gastointestiale blødninger.

\section{Profylakse med protonpumpehemmer}

Hos pasienter som bruker ikke-steroide antiinflammatoriske midler og/eller blodplatehemmere, kan profylakse med protonpumpehemmer redusere risikoen for blødende ulcus med ca. 70 \% (2). Protonpumpe- tilsvarende norske retningslinjer.

Alder er en viktig risikofaktor for blødende magesår og annen blødning fra øvre gastrointestinaltractus. Ved forskrivning til eldre bør man alltid vurdere om det aktuelle medikamentet øker risikoen for ulcus eller gastrointestinal blødning og eventuelt også forskrive protonpumpehemmer profylaktisk $(2,7)$.

Alle pasienter over 60 år som får ikkesteroide antiinflammatoriske midler eller platehemmer, bør få profylakse med protonpumpehemmer i følgende tilfeller:

- Tidligere ulcus ventriculi eller ulcus duodeni (ev. Helicobacter pylori-infeksjon bør også behandles)

- Tidligere blødning fra øvre gastrointestinaltractus

- Behandles med to platehemmere

- Behandles med både NSAID-preparat og platehemmer

- Behandles med både NSAID-preparat og steroider

- Behandles med NSAID-preparat eller platehemmer og samtidig får et antikoagulasjonsmiddel
Ved forskrivning til yngre gjøres individuell vurdering vedrørende risiko.

\section{Protonpumpehemmer \\ og klopidogrel}

Farmakokinetiske studier indikerer at protonpumpehemmer reduserer den platehemmende effekten av klopidigrel $(7,8)$. Det er imidlertid ikke vist at dette har klinisk betydning. Samtidig bruk av protonpumpehemmer og klopidogrel ser ikke ut til å gi flere kardiovaskulære hendelser enn klopidogrel brukt alene (7, 9-11). Hos klopidogrelbrukere kan det være et alternativ å gi høy dose H2-blokker, i form av ranitidin eller famotidin, i stedet for protonpumpehemmer (7).

\section{Profylakse med} protonpumpehemmer på blåresept I 2011 ble det godkjent å skrive ut protonpumpehemmer på blåresept for å forebygge magesår hos risikopasienter med behov for langtidsbehandling med ikke-steroide antiinflammatoriske midler. Forhåndsgodkjent refusjon etter $\S 2$ forutsetter at NSAID-preparatet brukes for en sykdom omfattet av blåreseptforskriften. For pasienter som bruker andre risikomedikamenter enn ikkesteroide antiinflammatoriske midler, må det eventuelt sendes individuell søknad til HELFO om å få det godkjent etter $\S 3$.

Det er behov for norske retningslinjer for profylakse med protonpumpehemmer eller $\mathrm{H} 2$-blokker hos pasienter som bruker risikomedikamenter, og de bør få det forhåndsgodkjent på blåresept.

\section{Taran Søberg}

taran.soberg@bluezone.no

Medisinsk avdeling

Sykehuset Østfold Fredrikstad

\footnotetext{
Taran Søberg (f. 1953) er spesialist i fordøyelsessykdommer og overlege ved Sykehuset $\emptyset$ stfold Fredrikstad.

Forfatter har fylt ut ICMJE-skjemaet og oppgir ingen interessekonflikter.
} 
Litteratur

1. Søberg T, Hofstad B, Sandvik L et al. Risikofaktorer for blødende magesår. Tidsskr Nor Legeforen 2010; 130: 1135-9.

2. Bhatt DL, Scheiman J, Abraham NS et al. ACCF/ ACG/AHA 2008 expert consensus document on reducing the gastrointestinal risks of antiplatelet therapy and NSAID use: a report of the American College of Cardiology Foundation Task Force on Clinical Expert Consensus Documents. J Am Coll Cardiol 2008: 52: 1502-17.

3. Nasjonalt folkehelseinstitutt. Legemiddelforbruket i Norge. www.legemiddelforbruk.no (20.10.2011).

4. Pradaxa «Boehringer Ingelheim». www.felleskatalogen.no/medisin/pradaxaboehringer-ingelheim-562917 (18.4.2012)

5. Xarelto «Bayer Pharma AG». www.felleskatalogen. no/medisin/xarelto-bayer-pharma-ag-565514 (18.4.2012).
6. Antitrombotiske midler (B01). www.felleskatalogen.no/medisin/atc-register/B01 (18.4.2012)

7. Abraham NS, Hlatky MA, Antman EM et al. ACCF/ ACG/AHA 2010 expert consensus document on the concomitant use of a proton pump inhibitor and thienopyridines: a focused update of the ACCF/ ACG/AHA 2008 expert consensus document on reducing the gastrointestinal risks of antiplatelet therapy and NSAID use. A Report of the American College of Cardiology Foundation Task Force on Expert Consensus Documents. J Am Coll Cardiol 2010; 56: 2051-66

8. Uchiyama S. Clopidogrel resistance: identifying and overcoming a barrier to effective antiplatelet treatment. Cardiovasc Ther 2011; 29: e100-11.

9. Bhatt DL, Cryer BL, Contant CF et al. Clopidogrel with or without omeprazole in coronary artery disease. N Engl J Med 2010; 363: 1909-17.
10. Hsiao FY, Mullins CD, Wen YW et al. Relationship between cardiovascular outcomes and proton pump inhibitor use in patients receiving dual antiplatelet therapy after acute coronary syndrome. Pharmacoepidemiol Drug Saf 2011: 20: 1043-9.

11. Leontiadis GI, Yuan Y, Howden CW. The interaction between proton pump inhibitors and clopidogrel and upper gastrointestinal bleeding. Gastrointest Endosc Clin N Am 2011; 21: 637-56.

Mottatt 12.12. 2011, første revisjon innsendt 12.3 . 2012, godkjent 18.4. 2012. Medisinsk redaktør Merete Kile Holtermann.

\title{
Svineinfluensavaksinen
}

\author{
Nå har det da vist seg at svineinfluensavaksinen ikke var så god som man trodde.
}

Allerede da vaksinen kom, var det en god del kritiske røster, men de ble dysset ned av Folkehelseinstituttets «sterke anbefaling» om massevaksinering, som gjorde at vi leger nærmest ble presset til å anbefale våre pasienter til å ta den.

Jeg var en av kritikerne - på bakgrunn av egen erfaring. I 1990, da jeg studerte medisin, var jeg prøvekanin for en ny vak- er til å dysse ned slike uønskede bieffekter - for å få solgt den kostbare vaksinen sin.

Men denne gang gikk det ikke bra med neddyssingen. Det er fint at denne skandalen er kommet frem i mediene. Jeg føler kraftig medynk med de stakkers 35 barna som på grunn av myndighetenes «sterke anbefalinger» nå må slite med narkolepsi resten av livet - en sykdom de ikke hadde

\section{«Én ting er å anbefale noe, noe helt annet er å påtvinge folk noe de er usikre på»}

sine som skulle på markedet i Tyskland, en hepatitt B-vaksine. Vi legestudenter fikk beskjed om at vi skulle vaksinere oss. Det ingen fortalte oss, var at det dreide seg om en eksperimentell vaksine og at vi var prøvekaninene! Det dukket opp en god del bivirkninger (f.eks. fikk en god venninne encefalitt etter vaksinen), og jeg opplevde allerede den gang hvor flinke myndighetene fått dersom de ikke hadde latt seg vaksinere.

Jeg ba pasientene mine vurdere vaksinering meget nøye. Og jeg frarådet gravide på det sterkeste å ta svineinfluensavaksinen - noe jeg nå $\mathrm{i}$ ettertid er meget glad for. Én ting er å anbefale noe, noe helt annet er å påtvinge folk noe de er usikre på. Høsten 2011 kunne man for eksempel bare få influ- ensavaksine som en kombinasjonsvaksine mot sesonginfluensa og svineinfluensa det fantes ikke to separate vaksiner slik at folk kunne velge mellom å ta begge eller bare sesonginfluensavaksinen. Dette er etter min mening forkastelig og uetisk.

Denne nærmest tvungne vaksineringen av folk med en eksperimentell vaksine er en stor skam og skandale for hele landet. Jeg er helt enig med professor i medisinsk etikk Jan Helge Solbakk: Helseministeren og lederen av Folkehelseinstituttet burde absolutt vurdere sine stillinger!

\section{Christina Grandalen}

shayarva@hotmail.com

Snertingdal

Christina Grandalen (f. 1968) er fastlege ved Snertingdal helsesenter i Gjøvik kommune. Ingen oppgitte interessekonflikter.

Mottatt 18.2. 2012 og godkjent 8.3. 2012. Medisinsk redaktør Anne Kveim Lie. 